KALAMATIKA Jurnal Pendidikan Matematika

Volume 2, No. 2, November 2017, hal. 177-192

$\mathbf{K} / \mathbf{L} \wedge \mathbf{M} / \mathbf{T} \mid \mathbf{K} \wedge$

\title{
DESAIN MODUL PEMBELAJARAN BERBASIS KEMAMPUAN KOMUNIKASI MATEMATIS DAN MOTIVASI BELAJAR SISWA
}

\author{
Sofi Saifiyah ${ }^{1}$, Ferry Ferdianto $^{2}$, Setiyani ${ }^{3}$ \\ ${ }^{1}$ Universitas Swadaya Gunung Jati Cirebon \\ samrrotul.janah@yahoo.co.id \\ ${ }^{2}$ Universitas Swadaya Gunung Jati Cirebon \\ ferrymatematika@gmail.com \\ ${ }^{3}$ Universitas Swadaya Gunung Jati Cirebon \\ setiyani_0401509081@yahoo.com
}

\begin{abstract}
ABSTRAK
Penelitian ini mengenai desain modul pembelajaran berbasis kemampuan komunikasi matematis dan motivasi belajar siswa. Jenis penelitian yang digunakan yaitu kualitatif deskriptif berupa penelitian desain didaktis. Penelitian dilatar belakangi oleh adanya hambatan belajar (learning obstacle) yang dialami siswa terkait materi persegi panjang dan persegi yang berkaitan dengan kemampuan komunikasi matematis pada siswa SMP kelas VII. Salah satu solusi untuk mengatasi learning obstacle yang dialami siswa yaitu mendesain modul pembelajaran agar dapat memfasilitasi siswa dalam memahami materi persegi panjang dan persegi serta mendorong kemampuan komunikasi matematisnya. Penelitian bertujuan untuk: (1) mengetahui learning obstacle yang dialami siswa; (2) mengetahui cara mendesain modul pembelajaran yang valid sesuai dengan learning obstacle yang dialami siswa; (3) mendeskripsikan intervensi guru dalam mengimplementasikan modul pembelajaran; dan (4) mengetahui motivasi belajar siswa setelah belajar menggunakan modul pembelajaran. Subjek penelitiannya yaitu siswa kelas VII SMP. Hasil dari penelitian ini menunjukkan adanya dua macam learning obstacle yang dialami oleh siswa, modul pembelajaran yang valid setelah direvisi sesuai saran dari kelima validator dengan persentase validasi modul pembelajaran mencapai $86,80 \%$ dengan kriteria sangat valid atau dapat digunakan tanpa revisi, intervensi yang dilakukan oleh guru pada saat mengimplementasikan modul pembelajaran berupa intervensi antisipasi didaktis dan pedagogis, serta rata-rata motivasi belajar siswa setelah belajar menggunakan modul pembelajaran mencapai $83,78 \%$ yang termasuk pada kategori motivasi belajar sangat kuat.
\end{abstract}

Kata Kunci : Komunikasi Matematis, Learning Obstacle, Modul Pembelajaran, Motivasi Belajar.

\begin{abstract}
This research about an instructional module design for mathematical communication skills and student motivation. This type of research is descriptive qualitative research in the form of a didactic design. Research background by the barriers to learning (learning obstacle) experienced by students regarding the material rectangle and related mathematical communication skills in junior high school students of class VII. One solution to overcome learning obstacles experienced by students is designing learning modules in order to facilitate the students to understand the material rectangular and square and encourage mathematical communication skills. The study aims to: (1) know learning obstacles experienced by students; (2) knowing how to design a learning module that is valid in accordance with
\end{abstract}


learning obstacles experienced by students; (3) describe the intervention of teachers in implementing the learning modules; and (4) determine students' motivation after learning using learning modules. His research interests are students of grade 7 of junior high school. The results of this study indicate the existence of two kinds of learning obstacles experienced by students, the learning module valid after being revised in accordance with the advice of the fifth validator validation learning modules percentage reached $86.80 \%$ with a very valid criteria or can be used without revision, intervention by teachers during the implementation of the learning modules in the form of anticipation of didactic and pedagogical intervention, and the average student motivation after learning to use the learning module reaches $83.78 \%$ which is included in the category of a very strong motivation to learn.

Keywords: Communication Mathematically, Learning Obstacle, Learning Module, Motivation.

Format Sitasi: Saifiyah, S., Ferdiyanto, F., \& Setiyani. (2017). Desain Modul Pembelajaran Berbasis Kemampuan Komunikasi Matematis dan Motivasi Belajar Siswa. KALAMATIKA Jurnal Pendidikan Matematika. 2(2), 177-192.

Penyerahan Naskah: 4 Juli 2017 || Revisi: 27 Juli 2017 || Diterima: 1 Agustus 2017

\section{PENDAHULUAN}

Pendidikan adalah usaha sadar yang dirancang sedemikian rupa untuk mencapai tujuan pembelajaran yang telah ditetapkan (Hamdani 2011). Menurut Tirtarahardja dan Sulo (2005) pendidikan adalah usaha sadar yang secara tidak langsung diarahkan kepada siswa dengan harapan siswa akan menjadi manusia yang memiliki kepribadian baik dan kuat serta bermoral tinggi. Berdasarkan penjelasan di atas dapat dikatakan bahwa pendidikan adalah proses perubahan sikap atau perilaku seseorang yang memiliki tujuan untuk menambah ilmu pengetahuan yang dimiliknya serta membentuk karakter diri untuk menjadi pribadi yang lebih baik.

Menurut Undang-Undang (UU) No.20 tahun 2003 Pasal 36 disebutkan bahwa pengembangan kurikulum dilakukan dengan mengacu pada standar nasional pendidikan untuk mewujudkan tujuan pendidikan nasional (Balitbang 2008). Suatu kurikulum disusun dan dilaksanakan sesuai dengan perkembangan dan kebutuhan yang diharapkan dengan tetap berpatokan pada standar nasional pendidikan yang menjadi pedoman bagi pengembangan kemampuan siswa secara optimal. Adapun kurikulum yang saat ini digunakan adalah Kurikulum Tingkat Satuan Pendidikan (KTSP) atau kurikulum 2006.

Salah satu mata pelajaran yang ada dalam kurikulum 2006 yaitu matematika. Matematika merupakan salah satu bidang ilmu yang sangat erat dengan kehidupan sehari-hari, maka pembelajaran akan lebih dapat dirasakan siswa jika setiap pembelajaran dikaitakan dengan kehidupan sehari-hari. Materi yang dapat dikaitkan dengan konteks kehidupan sehari- 
hari sangat banyak, salah satunya yaitu materi persegi panjang dan persegi. Beberapa permasalahan dalam kehidupan sehari-hari yang berhubungan dengan materi tersebut adalah menghitung keliling dan luas daerah ubin, meja, papan tulis, halaman rumah, dan lain-lain.

Berdasarkan hasil pengamatan penulis saat melaksanakan PPL di SMP Negeri 1 Palimanan, ditemukan bahwa banyak siswa yang mengalami hambatan saat belajar dan beranggapan matematika merupakan pelajaran yang sulit dan membosankan sehingga prestasi hasil belajar siswa tidak sesuai dengan yang mereka inginkan. Diantara penyebab hambatan belajar/learning obstacle tersebut adalah faktor siswa yang belum bisa menghubungkan materi yang dipelajarinya dengan situasi kehidupan nyata karena materi yang terdapat dalam bahan ajar yang digunakan siswa sulit untuk dipahami, sehingga siswa malas untuk mempelajarinya apa lagi untuk mengerjakan latihan-latihan soalnya.

Selain itu juga, bahan ajar yang mereka gunakan masih sangat terbatas dari segi materi, latihan soal, maupun contoh soalnya. Materi dalam bahan ajar yang mereka gunakan masih sangat singkat dan abstrak, sehingga dengan bahan ajar tersebut belum bisa membuat siswa untuk belajar mandiri karena masih membutuhkan penjelasan lebih banyak dari guru. Terbukti pada saat implementasi bahan ajar yang mereka gunakan dalam pembelajaran di kelas, guru masih kurang sigap dalam menanggapi berbagai respon yang muncul dari siswa. Terkadang saat siswa dihapakan pada suatu soal yang jawabannya tidak diketahui bahkan keliru, guru hanya sebatas memberikan jawabannya saja karena sebelum melaksakan pembelajaran guru tidak mengantisipasi jawaban diluar prediksi yang akan muncul pada saat pembelajaran, sehingga tujuan pembelajaran yang diharapkan tidak dapat tercapai.

Dalam mempelajari ilmu matematika siswa tidak hanya diajarkan untuk menghafal rumus-rumus matematika saja, melainkan siswa juga harus bisa menggunakan ilmu matematika untuk mengkomunikasikan supaya pemahamannya dapat dimengerti orang lain. Pengembangan kemampuan komunikasi matematis sesuai dengan hakekat matematika sebagai bahasa simbol yang efisien, padat makna, memiliki sifat keteraturan yang indah dan kemampuan analisis kuantitatif, bersifat universal dan dapat dipahami oleh setiap orang kapan dan dimana saja, dan membantu menghasilkan model matematika yang diperlukan dalam pemecahan masalah berbagai cabang ilmu pengetahuan dan masalah kehidupan sehari-hari (Sumarmo, 2015:4). Kemampuan komunikasi matematis adalah kemampuan dalam menulis, membaca, menyimak, menelaah, menginterpretasikan dan mengevaluasi ide, simbol, istilah, 
dan informasi matematis (Afgani 2011). Dengan demikian komunikasi matematis merupakan salah satu kemampuan di mana siswa ditantang untuk memahami ide-ide maupun simbol matematika dan menyampaikan hasilnya kepada orang lain baik secara verbal maupun tertulis.

Berdasarkan hasil wawancara dengan salah satu guru matematika kelas VII SMP Negeri 1 Palimanan, diperoleh keterangan bahwa kemampuan komunikasi matematis siswa masih tergolong rendah. Menurut guru tersebut, kurangnya kemampuan komunikasi matematis tersebut dilihat dari 1) ketika siswa dihadapkan pada soal cerita, siswa tidak terbiasa menuliskan apa yang diketahui dan apa yang ditanyakan dari soal sebelum menyelesaikannya, sehingga siswa sering keliru dalam menafsirkan maksud dari soal tersebut; 2) kurangnya ketepatan siswa dalam menjelaskan ide matematis dengan benda nyata, gambar dan aljabar, hal ini menyebabkan siswa masih belum bisa menggambarkan atau mengilustrasikan suatu bentuk soal matematika. Terbukti dari hasil uji coba soal kemampuan komunikasi yang diberikan kepada siswa yang sudah mendapatkan materi persegi panjang dan persegi yaitu siswa kelas VIII SMP Negeri 1 Palimanan, siswa cenderung belum mampu menyelesaikan soal dengan tepat karena tidak sedikit siswa mengalami hambatan dalam menyelesaikan soal terkait keliling dan luas persegi panjang dan persegi tersebut, salah satunya pada indikator menyatakan peristiwa sehari-hari dalam bahasa atau simbol matematika dan menjelaskan ide matematis dengan gambar dan aljabar.

Masih berdasarkan hasil wawancara dengan guru matematika, selain rendahnya kemampuan komunikasi matematis, siswa juga merasa kurang termotivasi dalam belajar matematika sehingga hasil belajar yang dicapai tidak sesuai dengan yang diharapkan. Padahal dengan motivasi siswa akan menjadi lebih aktif dalam belajar dan berani bertanya kepada guru jika mengalami kesulitan dalam belajar. Motivasi merupakan kekuatan untuk mendorong seseorang dalam melakukan sesuatu hingga mencapai tujuan tertentu (Uno 2015). Oleh sebab itu, motivasi sangatlah penting dimiliki oleh setiap siswa khususnya dalam belajar matematika sebab dengan adanya kekuatan tersebut maka segala harapan dan tujuan yang dibutuhkan dapat terpenuhi karena adanya kemauan yang kuat.

Berdasarkan permasalahan-permasalahan dan hambatan belajar/learning obstacle yang telah dipaparkan di atas, perlu adanya suatu bahan ajar matematika yang memuat materi pembelajaran dengan kemampuan komunikasi matematis. Oleh karena itu, sebagai solusi penulis tertarik untuk melakukan penelitian yang berjudul "Desain Modul Pembelajaran 
Berbasis Kemampuan Komunikasi Matematis dan Motivasi Belajar Siswa" dengan beberapa rumusan masalah diantaranya, 1) bagaimana learning obstacle siswa terkait kemampuan komunikasi matematis pada materi persegi panjang dan persegi?; 2) bagaimana mendesain modul pembelajaran berbasis kemampuan komunikasi matematis pada materi persegi panjang dan persegi yang valid?; 3) bagaimana intervensi guru dalam implementasi modul pembelajaran berbasis kemampuan komunikasi matematis pada materi persegi panjang dan persegi?; dan 4) bagaimana motivasi belajar siswa dalam belajar matematika menggunakan modul pembelajaran berbasis kemampuan komunikasi matematis?

\section{METODE PENELITIAN}

Metode yang digunakan dalam penelitian ini menggunakan metode DDR (Didactical Design Research) bersifat kualitatif deskriptif. Subjek penelitian dalam implementasi modul pembelajaran adalah siswa SMP Negeri 1 Palimanan kelas VII C yang terdiri dari 36 siswa, sedangkan subjek uji coba soal untuk mengetahui learning obstacle adalah siswa kelas VIII B SMP Negeri 1 Palimanan yang terdiri atas 36 siswa.

Dilakukannya penelitian ini untuk menyusun suatu desain modul pembelajaran berdasarkan learning obstacle terkait materi persegi panjang dan persegi sehingga diharapkan dapat meminimalisir learning obstacle. Penelitian disain didaktis memiliki tiga tahap, yaitu 1) analisis situasi didaktis sebelum pembelajaran yang wujudnya berupa Desain Didaktis Hipotesis termasuk ADP (Antisipasi Didaktis dan Pedagogis); 2) analisis metapedadidaktis; 3) analisis retrosfektif yakni analisis yang mengaitkan hasil analisis situasi didaktis hipotesis dengan hasil analisis metapedadidaktik (Suryadi 2013).

Teknik pengumpulan data yang digunakan meliputi tes kemampuan komunikasi matematis untuk mengetahui learning obstacle siswa, wawancara dengan guru matematika kelas VII, lembar validasi modul pembelajaran untuk mengetahui tingkat validasi modul, tabel antisipasi untuk mengetahui intervensi guru, dan angket motivasi belajar untuk mengetahui motivasi belajar siswa setelah belajar menggunakan desain modul pembelajaran berbasis kemampuan komunikasi matematis. Adapun teknik pengolahan data dalam penelitian kualitatif ini dilakukan sejak sebelum memasuki lapangan, selama di lapangan, dan setelah selesai di lapangan. 


\section{HASIL DAN PEMBAHASAN}

Learning obstacle diperoleh dengan melakukan uji coba soal. Berdasarkan hasil uji coba, diketahui kemampuan mengerjakan soal dan learning obstacle siswa dalam memahami materi persegi panjang dan persegi. Salah satunya pada soal uji coba nomor 8 yaitu "Sebuah lukisan berbentuk persegi panjang dengan lebar $65 \mathrm{~cm}$ dan kelilingnya $330 \mathrm{~cm}$. Ilustrasikan situasi tersebut dan hitunglah panjang serta luas daerah lukisan!”. Indikator kemampuan soal tersebut yaitu menghitung panjang persegi panjang, menghitung luas daerah persegi panjang, dan menggambar situasi soal. Gambar 1 berikut menunjukkan bahwa terdapat learning obstacle yang dialami siswa dalam menjawab soal nomor 8 .



Gambar 1. Contoh Pengerjaan Siswa Pada Soal Nomor 8

Gambar 1 menunjukkan siswa mengalami learning obstacle dalam menyelesaikan soal nomor 8 dikarenakan siswa tidak menuliskan terlebih dahulu apa yang diketahui dan apa yang ditanyakan dalam soal, sehingga siswa hanya menyelesaikan soal ini sampai mendapatkan nilai panjang dari lukisan saja. Sedangkan luas daerah lukisan dan ilustrasi bentuk lukisan yang diminta dalam soal, siswa tidak menjawabnya karena kurangnya kemampuan siswa dalam menjelaskan situasi matematis dengan benda nyata, selain itu juga karena kurangnya kemampuan siswa dalam menyatakan peristiwa sehari-hari dalam bahasa atau simbol matematika sehingga siswa tidak dapat menyelesaikan soal ini dengan benar. Dari 36 siswa yang mengerjakan soal nomor 8 ini, hanya sekitar $28,00 \%$ saja siswa yang dapat menyelesaikan soal dengan benar. Kemampuan siswa dalam mengerjakan soal komunikasi matematis yang lainnya disimpulkan dalam Tabel 1 berikut. 
Tabel 1. Distribusi Kemampuan Siswa dalam Mengerjakan Soal Kemampuan Komunikasi Matematis

\begin{tabular}{|c|c|c|}
\hline $\begin{array}{l}\text { No } \\
\text { soal }\end{array}$ & Indikator Kemampuan Mengerjakan Soal & $\begin{array}{c}\text { Responden } \\
(\%)\end{array}$ \\
\hline \multirow[t]{2}{*}{1} & a. Menghitung luas daerah saputangan (persegi) & $86,11 \%$ \\
\hline & b. Menghitung keliling saputangan (persegi) & $83,33 \%$ \\
\hline \multirow[t]{3}{*}{2} & a. Menghitung luas daerah persegi panjang (foto) & $80,56 \%$ \\
\hline & b. Menghitung luas daerah persegi (bingkai) & $83,33 \%$ \\
\hline & c. Menghitung luas daerah bingkai yang tidak tertutup foto & $69,44 \%$ \\
\hline \multirow[t]{3}{*}{3} & $\begin{array}{l}\text { d. Menggambar situasi bingkai dan foto dengan ukuran yang sudah diketahui } \\
\text { a. Menghitung luas daerah persegi panjang (taplak meja) }\end{array}$ & $\begin{array}{l}55,56 \% \\
94,44 \%\end{array}$ \\
\hline & b. Menghitung keliling persegi panjang (taplak meja) & $94,44 \%$ \\
\hline & c. Mengubah satuan taplak meja & $13,89 \%$ \\
\hline \multirow[t]{5}{*}{4} & a. Menghitung luas daerah persegi panjang & $86,11 \%$ \\
\hline & b. Menghitung keliling persegi panjang & $58,33 \%$ \\
\hline & c. Menghitung nilai panjang persegi panjang & $86,11 \%$ \\
\hline & d. Menghitung luas daerah persegi & $83,33 \%$ \\
\hline & e. Menggambar situasi sesuai dengan keadaan soal & $27,78 \%$ \\
\hline \multirow[t]{4}{*}{5} & a. Menghitung nilai $x$ & $83,33 \%$ \\
\hline & b. Mensubstitusikan nilai $\mathrm{x}$ ke salah satu persamaan panjang sisi persegi & $75,00 \%$ \\
\hline & c. Menghitung panjang sisi persegi $\mathrm{ABCD}$ & $75,00 \%$ \\
\hline & d. Menghitung keliling persegi $\mathrm{ABCD}$ & $61,11 \%$ \\
\hline \multirow[t]{2}{*}{6} & a. Menghitung keliling kebun & $52,78 \%$ \\
\hline & b. Menghitung banyak pohon & $52,78 \%$ \\
\hline \multirow[t]{4}{*}{7} & a. Menghitung luas daerah lantai aula & $58,33 \%$ \\
\hline & b. Menghitung luas daerah ubin & $63,89 \%$ \\
\hline & c. Mengubah satuan & $0,00 \%$ \\
\hline & d. Menghitung banyak ubin yang diperlukan & $0,00 \%$ \\
\hline \multirow[t]{3}{*}{8} & a. Menghitung panjang persegi panjang & $25,00 \%$ \\
\hline & b. Menghitung luas daerah persegi panjang & $36,11 \%$ \\
\hline & c. Menggambar situasi soal & $22,22 \%$ \\
\hline \multirow[t]{5}{*}{9} & a. Menghitung keliling lahan kosong & $38,89 \%$ \\
\hline & b. Menghitung luas daerah lahan kosong & $38,89 \%$ \\
\hline & c. Menghitung luas daerah lapangan basket & $38,89 \%$ \\
\hline & d. Menghitung luas daerah taman & $38,89 \%$ \\
\hline & e. Menggambar situasi soal & $33,33 \%$ \\
\hline
\end{tabular}

Tabel 1 menjelaskan distribusi kemampuan siswa dalam mengerjakan soal persegi panjang dan persegi dengan kemampuan komunikasi matematis. Distribusi hasil pengerjaan siswa tersebut terlihat bahwa siswa masih banyak yang belum bisa menyelesaikan soal-soal dengan tepat. Begitu pun dengan kemampuan komunikasi matematisnya, sebagian besar siswa memiliki kemampuan komunikasi matematis yang rendah sehingga masih banyak hambatanhambatan yang muncul dalam menyelesaikan soal. Padahal kemampuan komunikasi matematis memiliki peran yang penting bagi siswa, selain membina konsep juga, membina 
kaitan antara ide dan bahasa abstrak dengan simbol matematika (Astuti dan Leonard 2010). Melalui soal berbasis kemampuan komunikasi ini, akan terlihat sejauh mana kemampuan siswa mengeksplorasi pemikiran dan pemahaman mereka terhadap materi matematika (Rosita 2014).

Analisis kemampuan siswa dalam mengerjakan soal terkait materi persegi panjang dan persegi menunjukkan terdapat dua macam learning obstacle, yaitu 1) learning obstacle terkait konsep-konsep dalam materi persegi panjang dan persegi. Learning obstacle ini terbagi menjadi 3 macam yaitu a) learning obstacle dalam menghitung keliling dan luas daerah persegi panjang. Pada learning obstacle ini sebagian besar siswa mengalami kekeliruan dalam menentukan salah satu unsur dari persegi panjang jika keliling atau luas daerah persegi panjangnya yang diketahui; b) learning obstacle dalam menghitung keliling dan luas daerah persegi. Pada learning obstacle ini umumnya siswa mengalami kekeliruan dalam menggunakan konsep rumus yang harus digunakan, untuk mencari keliling persegi mereka tertukar malah menggunakan rumus luas daerah persegi; dan c) learning obstacle dalam menyelesaikan masalah sehari-hari yang berkaitan dengan persegi panjang dan persegi. Sedangkan pada learning obstacle ini, siswa mengalami kekeliruan dalam menggunakan konsep rumus keliling, padahal dalam soal sudah jelas terdapat kata kunci keliling yaitu "jika disekeliling taman akan ditanami bunga" tetapi siswa masih banyak yang keliru malah menggunakan konsep rumus luas daerah. Selain itu juga kekeliruan siswa yang banyak dialami pada learning obstacle ini pada saat siswa harus menggambarkan atau mengilustrasikan situasi sesuai dengan soal, masih banyak siswa yang tidak dapat mengilutrasikan situasi soal dengan baik dan benar karena kebanyakan siswa hanya menghafal materinya saja, tidak mengaplikasikannya dalam kehidupan sehari-hari (Mukhtar 2013); 2) Learning obstacle terkait mengaitkan konsep yang ada dalam materi persegi pajang dan persegi dengan konsep materi lain. Learning obstacle tersebut sesuai dengan pendapat Rahmawati (2013) bahwa suatu topik dalam matematika lebih sukar dipahami bila terpisah dengan topik yang lain. Pada learning obstacle ini sebagian besar siswa umumnya mengalami kekeliruan pada saat harus mengubah satuan luas sentimeter kuadrat $\left(\mathrm{cm}^{2}\right)$ menjadi meter kuadrat $\left(\mathrm{m}^{2}\right)$ ataupun sebaliknya. Selain dalam mengubah satuan, siswa juga tidak selalu menuliskan satuan pada setiap penjumlahan suatu sisi atau perkalian antar sisi, sehingga 
setelah menghitung hasil akhir biasanya siswa mengalami kekeliruan untuk satuan luas dan satuan keliling.

\section{Validasi Modul Pembelajaran}

Desain modul pembelajaran dikembangkan berdasarkan learning obstacle yang dialami siswa terkait materi persegi panjang dan persegi serta hasil wawancara dengan guru matematika kelas VII SMP Negeri 1 Palimanan. Sebelum modul tersebut diimplementasikan maka perlu dilakukan validasi terlebih dahulu. Hal tersebut dilakukan untuk mengetahui apakah desain modul pembelajaran yang telah disusun valid atau tidaksehingga mengahsilkan suatu modul pembelajaran yang baik yang sangat berperan pentig untuk membantu poses pembelajaran di dalam kelas (Shulhany dkk, 2015). Kelayakan desain modul pembelajaran yang telah disusun dapat diketahui berdasarkan hasil lembar validasi modul pembelajaran yang telah diserahkan kepada validator atau para ahli. Pada penelitian ini terdapat lima ahli yang diantaranya tiga dosen pendidikan matematika Unswagati Cirebon dan dua guru matematika SMP Negeri 1 Palimanan.

Skor yang diperoleh dari kelima ahli yaitu ahli 1sebesar $80 \%$ dengan kriteria cukup valid atau dapat digunakan namun perlu direvisi kecil karena menurut beliau kekurangan dari modul ini hanya tidak adanya indikator kompetensi dan indikator kemampuan pada awal setiap petemuan, ahli 2 sebesar $90 \%$ dengan kriteria sangat valid atau dapat digunakan tanpa revisi karena menurut ahli 2 kekurangan pada modul hanya terletak pada beberapa kata yang memerlukan kejelasan untuk memperjelas kalimat tersebut dan karena desain modul sudah memenuhi seluruh komponen yang ada dalam penilaian, ahli 3 sebesar $74 \%$ dengan kriteria cukup valid atau dapat digunakan namun perlu direvisi kecil karena pada modul tersebut belum terdapat pengantar kasus untuk masuk ke dalam materi dan juga contoh soalnya terlalu dibimbing, ahli 4 sebesar $95 \%$ dengan kriteria sangat valid atau dapat digunakan tanpa revisi karena menurut beliau modulnya memiliki desain yang sangat menarik siswa dan juga soalsoalnya sangat bervariasi serta kekinian atau bukan soal cerita yang sudah lama, dan ahli 5 sebesar $95 \%$ dengan kriteria sangat valid atau dapat digunakan tanpa revisi karena menurut ahli 5 desain modul sudah sistematis dan bahasa yang digunakan dalam modul mudah dipahami siswa. Hasil dari kelima validasi ini kemudian dicari rata-ratanya yaitu 86,80\% dengan kriteria sangat valid atau dapat digunakan tanpa revisi. Hal ini menunjukkan bahwa modul pembelajaran dapat diimplementasikan di dalam kelas. Walaupun hasil yang diperoleh 
menunjukkan kriteria yang sangat valid atau tanpa revisi tetapi, masukan dari para ahli dijadikan bahan pertimbangan untuk menyempurnakan modul pembelajaran. Sehingga modul pembelajaran diperbaiki terlebih dahulu sesuai dengan saran validator dan kemudian diimplementasikan di dalam kelas.

\section{Intervensi Guru}

Desain modul pembelajaran ini diimplementasikan di kelas VII C SMP Negeri 1 Palimanan. Desain modul pembelajaran mengenai konsep persegi panjang dan persegi diterapkan tiga kali pertemuan. Pada pertemuan pertama diterapkan materi keliling dan luas daerah persegi panjang dengan memberikan situasi didaktis sebanyak 6 situasi, pada pertemuan kedua diterapkan materi keliling dan luas daerah persegi dengan memberikan situasi didaktis sebanyak 7 situasi, dan pada pertemuan ketiga diterapkan materi penyelesaian masalah yang berkaitan dengan keliling dan luas daerah persegi panjang dan persegi dalam kehidupan sehari-hari dengan memberikan situasi didaktis sebanyak 6 situasi.

Intervensi guru dalam mengimplementasikan modul pembelajaran dengan kemampuan komunikasi matematis pada kelas tersebut sebagai fasilitator. Guru memfasilitasi siswa ketika siswa mengalami hambatan dalam mempelajari atau mengerjakan latihan soal pada modul. Selain itu, guru juga membimbing dan mengarahkan siswa selama kegiatan belajar berlangsung sesuai dengan tujuan pembelajaran yang diharapkan. Peran guru dalam implementasi modul pembelajaran ini merupakan peran pedagogis (antisipasi pedagogis) sesuai dengan salah satu komponen segitiga didaktis yang dibuat oleh Suryadi (2013). Melalui respons siswa terhadap hambataan belajar yang dialaminya, guru dapat memberikan intervensinya dengan menciptakan situasi-situasi belajar baru untuk mengantisipasi hambatan tersebut.

Intervensi antisipasi pedagogis merupakan peran guru saat mengimplementasikan desain modul pembelajaran. Sedangkan intervensi antisipasi didaktis merupakan intervensi guru secara tidak langsung yang tertuang dalam modul. Guru berperan ketika respons siswa terhadap desain modul pembelajaran tidak sesuai dengan prediksi respons yang telah dibuat sebelumnya. Peran pedagogis diberikan untuk mengatasi permasalahan diluar prediksi respons tersebut secara langsung pada saat pembelajaran, sehingga tidak menimbukan kekeliruankekeliruan baru ketika siswa menggunakan desain modul pembelajaran. 
Hasil dari penelitian yang sudah dilakukan, ternyata hanya sedikit saja respon siswa yang diluar dari prediksi yang sudah dipersiapkan sebelumnya karena antisipasi didaktis yang telah dibuat sebelumnya yang tertuang dalam modul pembelajaran sudah mampu mengatasi learning obstacle yang mereka hadapi. Sehingga, intervensi guru pada saat pembelajaran sesuai dengan yang telah dipersiapkan.Secara umum implementasi desain modul pembelajaran ini sesuai dengan prediksi respons siswa yang telah dibuat oleh penulis sebelum memasuki kelas.

\section{Motivasi Belajar Siswa}

Motivasi belajar siswa dinilai melalui angket yang sengaja diberikan oleh penulis untuk diisi oleh siswa. Angket berisikan 20 pernyataan yang telah dibuat oleh penulis sesuai dengan indikator motivasi belajar siswa.Angket tersebut kemudian dibagikan kepada siswa setelah selesai proses belajar dengan menggunakan modul pembelajaran pada pertemuan terakhir yaitu pertemuan ketiga.

Sebanyak 36 siswa yang mengisi angket motivasi belajar yang tersedia. Setelah mendapatkan data angket, tahap selanjutnya menganalisis tiap pernyataan yang ada dalam angket tersebut. Dari hasil data angket menunjukkan bahwa motivasi belajar siswa sangat kuat setelah belajar menggunakan modul pembelajaran berbasis kemampuan komunikasi matematis pada materi persegi panjang dan persegi. Dari 12 pernyataan positif yaitu pernyataan nomor 1 , $2,3,8,9,10,11,14,16,17,19$, dan 20 semuanya menghasilkan motivasi yang sangat kuat. Adapun 8 pernyataan negatif yaitu pernyataan nomor 4, 5, 6, 7, 12, 13, 15, dan 18 diperoleh 6 pernyataan yaitu 5, 6, 7, 12, 13, dan 15 menghasilkan motivasi yang sangat kuat, sedangkan 2 pernyataan lainnya yaitu pernyataan nomor 4 dan 18 menghasilkan motivasi yang kuat. Kuatnya motivasi belajar siswa dalam hal ini merupakan salah satu upaya yang dilakukan penulis sesuai dengan prinsip yang dikemukakan oleh Hamdani (2011: 221) untuk menunjang keberhasilan belajar siswa dan juga memberikan latihan kepada siswa untuk menguji kemampuannya. Berikut rekapitulasi pernyataan angket motivasi belajar siswa setelah belajar menggunakan modul pembelajaran. 


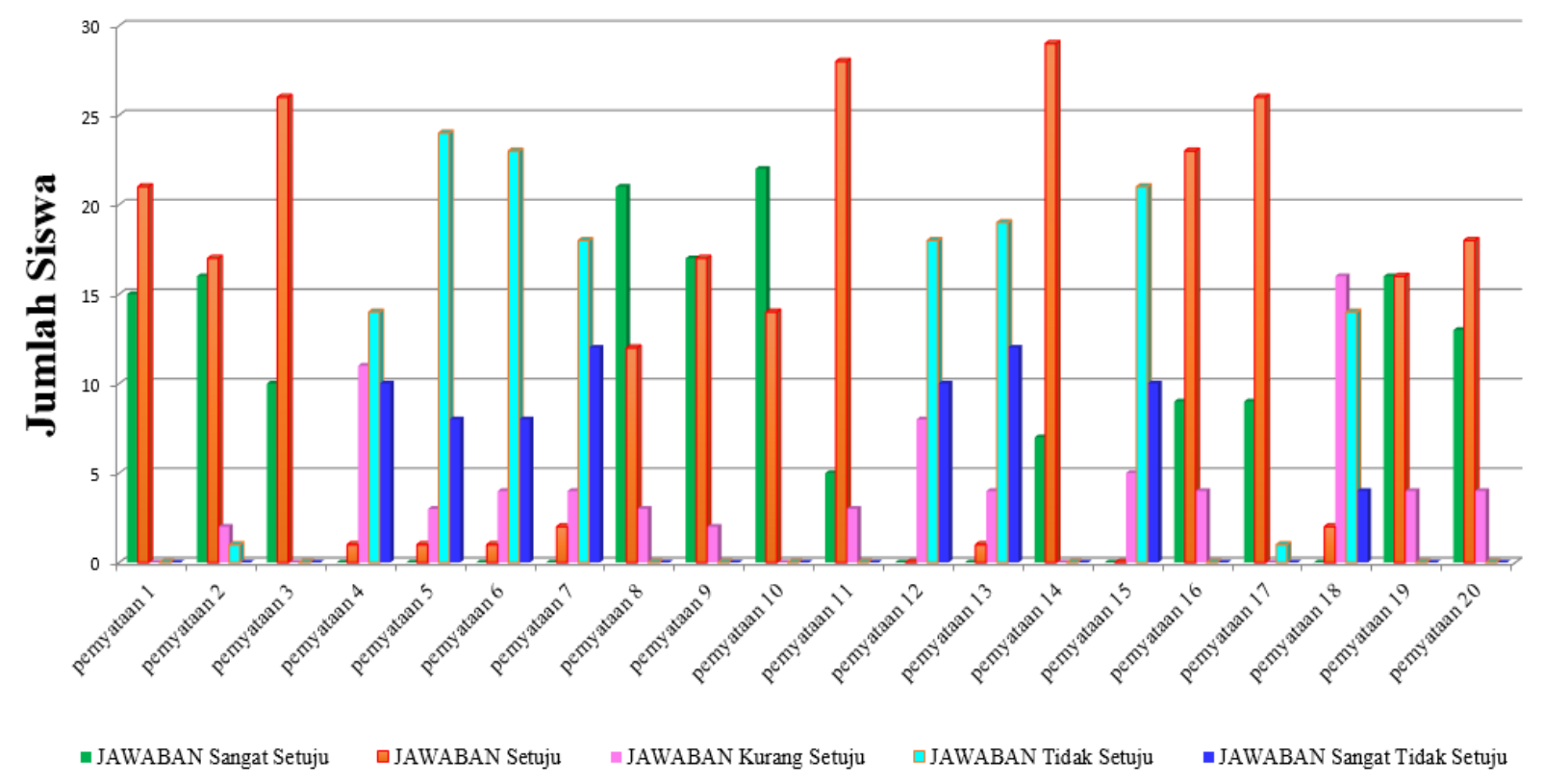

Gambar 2. Rekapitulasi Pernyataan Angket Motivasi Belajar Siswa

Pernyataan postif yang mendapatkan hasil paling banyak dari 18 pernyataan positif adalah pernyataan nomor 14 yaitu "saya menjadi lebih bersemangat belajar matematika ketika menggunakan modul karena saya dapat menghubungkan benda nyata dan gambar ke dalam ide matematika" dengan pilihan jawaban "setuju" sebanyak 29 siswa, pilihan jawaban "sangat setuju" sebanyak 7 siswa, dan jawaban lainnya seperti "kurang setuju”, "tidak setuju”, serta "sangat tidak setuju" tidak ada yang memilih. Penyebab pernyataan nomor 14 ini banyak siswa yang memilih jawaban "setuju" dikarenakan siswa terdorong supaya dapat menyelesaikan soal yang berbentuk gambar untuk dihubungkan ke dalam ide matematika dan juga karena siswa membutuhkan modul pembelajaran untuk menunjang proses belajarnya.

Pernyataan positif lainnya yaitu pernyataan nomor 11 tidak jauh berbeda dengan pernyataan nomor 14 yaitu "saya sangat antusias mengerjakan latihan soal menjelaskan ide, situasi, dan relasi matematis secara tulisan dengan benda nyata, gambar, dan aljabar yang ada di dalam modul", untuk jawabannya hanya 28 siswa yang memilih jawaban "setuju", 5 siswa memilih jawaban "sangat setuju", dan 3 siswa memilih jawaban "kurang setuju". Jawaban "tidak setuju" dan "sangat tidak setuju" tidak ada yang memilih. Penyebab pernyataan nomor 11 ini banyak siswa yang memilih jawaban "setuju" dikarenakan siswa memiliki keinginan untuk dapat mengerjakan soal situasi matematis menjadi sebuah benda nyata atau gambar dan aljabar yang ada di dalam modul. 
Sedangkan pernyataan negatif yang menghasilkan jawaban paling banyak terdapat pada pernyataan nomor 5 yaitu "saya malas mengerjakan latihan soal menghubungkan benda nyata dan gambar ke dalam ide matematika yang ada di dalam modul" dengan pilihan jawaban "tidak setuju" sebanyak 24 siswa, "sangat tidak setuju" 8 siswa, "kurang setuju" 3 siswa, "setuju" 1 siswa, dan "sangat setuju" tidak ada yang memilih. Penyebab pernyataan nomor 5 ini banyak siswa yang memilih jawaban "tidak setuju" dikarenakan siswa memiliki hasrat dan keinginan untuk mengerjakan latihan soal dalam menghubungkan benda nyata atau gambar ke dalam ide matematika yang ada di dalam modul.

Berdasarkan motivasi belajar siswa yang diperoleh dari angket yang telah disebarkan, diperoleh persentase keseluruhan motivasi belajar siswa sebesar 83,78\% yang termasuk pada kategori motivasi belajar sangat kuat. Motivasi belajar siswa sangat kuat ini dikarenakan dalam proses pembelajarannya siswa menggunakan suatu modul pembelajaran yang dapat melatih dirinya untuk belajar secara mandiri ataupun berdiskusi dengan kelompoknya. Selain itu juga modul yang digunakan siswa mampu menarik minat siswa untuk belajar karena desain modul yang menarik dan juga bahasa yang digunakan dalam modul mudah dipahami dan dimengerti.

Motivasi belajar siswa sangat kuat juga terlihat pada saat siswa belajar menggunakan modul yang penulis bagikan, siswa sangat antusias bertanya apabila terdapat contoh soal ataupun materi yang kurang mereka pahami, karena mereka selalu ingin dapat menyelesaikan semua soal yang penulis tugaskan dengan benar dan tepat. Sangat kuatnya motivasi belajar siswa dikarenakan penggunaan modul dalam proses pembelajaran, sejalan dengan pendpat Hamdani (2011) yang menyatakan bahwa motivasi belajar dapat dibangkitkan, ditingkatkan, dan dipelihara oleh kondisi-kondisi luar, seperti penyajian pelajaran oleh guru dengan menggunakan media yang bervariasi. Sehingga dapat dikatakan bahwa pembelajaran dengan menggunakan desain modul pembelajaran dapat diterima oleh siswa sebagai sebuah bahan ajar baru yang dapat memberikan motivasi belajar yang sangat kuat.

\section{KESIMPULAN}

Berdasarkan hasil penelitian, kesimpulan yang dapat diambil bahwa learing obstacle yang ditemukan terbagi menjadi dua tipe, yaitu: tipe 1 mengenai learning obstacle terkait konsep-konsep yang ada dalam materi persegi panjang dan persegi dan tipe 2 mengenai larning obstacle terkait mengaitkan konsep-konsep yang ada dalam materi persegi panjang 
dan persegi dengan konsep-konsep materi matematika lain. Secara umum learning obstacle yang dialami siswa pada materi persegi panjang dan persegi disebabkan oleh kurangnya penguasaan siswa pada materi prasyarat, kurangnya kemampuan siswa dalam mengkomunikasikan suatu ide atau situasi matematis dengan benda nyata, gambar dan aljabar, kurangnya kemampuan siswa dalam menghubungkan benda nyata atau gambar ke dalam ide matematika, dan kurangnya kemampuan siswa dalam menyatakan peristiwa sehari-hari dalam bahasa atau simbol matematika.

Desain modul pembelajaran berbasis kemampuan komunikasi matematis ini disusun berdasarkan learning obstacle yang telah dianalisis. Kelayakan modul dinilai oleh lima orang ahli yang menghasilkan nilai validasi sebesar $86,80 \%$ dengan tingkat validasi sangat valid, atau dapat digunakan tanpa revisi. Namun masukan dari para ahli dijadikan bahan pertimbangan untuk menyempurnakan modul pembelajaran yang akan diimplementasikan. Oleh karena itu, dapatdisimpulkan bahwa desain modul pembelajaran berbasis kemampuan komunikasi matematis layak digunakan dalam proses pembelajaran materi persegi panjang dan persegi.

Intervensi guru dalam mengimplementasikan desain modul pembelajaran memiliki dua intervensi yaitu berupa intervensi antisipasi didaktis dan antisipasi pedagogis. Intervensi antisipasi didaktis merupakan intervensi yang dilakukan guru secara tidak langsung yang tertuang dalam modul pembelajaran. Sedangkan intervensi antisipasi pedagogis diberikan secara langsung pada saat modul pembelajaran diimplememtasikan dengan disesuaikan dari respons yang diberikan siswa. Hasil penelitian yang sudah dilakukan hanya sedikit saja respons siswa yang diluar dari prediksi yang sudah dipersiapkan sebelumya. Sehingga, intervensi guru pada saat pembelajaran sesuai dengan yang telah dipersiapkan.

Motivasi belajar siswa setelah belajar dengan menggunakan modul pembelajaran termasuk kategori "Sangat Kuat". Hal ini berdasarkan hasil rata-rata dari 20 pernyataan sebesar 83,78\%. Dengan demikian, pembelajaran dengan menggunakan modul pembelajaran berbasis kemampuan komunikasi matematis khususnya pada materi persegi panjang dan persegi dapat diterima oleh siswa sebagai suatu bahan ajar baru yang dapat memeberikan motivasi belajar siswa yang sangat kuat. 


\section{REKOMENDASI}

Saran yang diajukan berdasarkan kesimpulan yang diambil bahwa pengetahuan dan penguasaan konsep materi prasyarat yang berhubungan dengan materi persegi panjang dan persegi harus lebih dikuasai siswa. Desain modul pembelajaran yang telah disusun dalam penelitian ini dapat dijadikan suatu alternatif media cetak yang dapat digunakan pada proses pembelajaran matematika, namun penggunaan desain modul pembelajaran harus disesuaikan dengan kondisi siswa. Penelitian terkait desain modul pembelajaran ini diharapkan dapat terus berkembang sehingga menghasilkan susunan modul pembelajaran yang lebih baik lagi terutama untuk meningkatkan kemampuan komunikasi matematis siswa tehadap materi persegi panjang dan persegi. Menggunakan media pembelajaran disetiap proses belajar mengajar yang sesuai dengan karakter atau lingkungan siswa khususnya pada materi persegi panjang dan persegi sehingga dapat meningkatkan motivasi belajar siswa.

\section{REFERENSI}

Afgani, D. (2011). Analisis Kurikulum Matematika. Jakarta: Universitas Terbuka.

Akbar, S. (2013). Instrumen Perangkat Pembelajaran. Bandung: Remaja Rosdakarya.

Astuti, A., \& Leonard. (2010). Peran Kemampuan Komunikasi matematika Terhadap Prestasi Belajar Matematika Siswa. Jurnal Formatif Fakultas Teknik Matematika dan IPA Universitas Indraprasta PGRI.

BSNP. (2006). Panduan Penyususnan Kurikulum Tingkat Satuan Pendidikan Jenjang Pendidikan Dasar dan Menengah. Jakarta: Depdiknas.

Balitbang. (2008). Evaluasi Pelaksanaan KTSP oleh Tim Pengembang Kurikulum Propinsi. Jakarta: Depdiknas.

Darkasyi, dkk. (2014). Peningkatan Kemampuan Komunikasi Matematis dan Motivasi Siswa dengan Pembelajaran Pendekatan Quantum Learning pada Siswa SMP Negeri 5 Lhokseumawe. Jurnal Didaktik Matematika Vol. 1, No. 1, April 2014.

Hamdani. (2011). Strategi Belajar Mengajar. Bandung: Putaka Setia.

Hudson, B. (2008). A Didactical Design Perspective on Teacher Presence in an International Online Learning Community. Umea University, 15, 3-4.

Jihad, A. (2008). Pengembangan Kurikulum Matematika. Yogyakarta: Multi Pressindo. 
Mukhtar. (2013). Pengembangan bahan Ajar Matematika Berbasis Masalah untuk Memfasilitasi Pencapaian Kemampuan Penalaran dan Pemahaman Konsep Siswa. Prosiding Semirata FMIPA Universitas Lampung.

Nurhayati, D. (2011). Motivasi dan Prestasi Belajar Siswa dalam Pembelajaran Matematika Ditinjau dari Kelekatan Anak-Orang Tua. Prosiding Seminar Nasioanl Matematika dan Pendidikan matematika FMIPA UNY.

Rahmawati, F. (2013). Pengaruh Pendekatan Pendidikan Realistik Matematika dalam Meningkatkan Kemampuan Komunikasi Matematis Siswa Sekolah Dasar. Makalah disampaikan pada seminar semirata Fakultas MIPA Universitas Lampung.

Rosita, C.D. (2014). Kemampuan Penalaran dan Komunikasi Matematis: Apa, Mengapa, dan Bagaimana Ditingkatkan Pada mahasiswa. Euclid, 1(1), 1-59.

Shulhany, M.A, dkk. (2015). Pengembangan Bahan Ajar Dimensi Tiga dengan Pendekatan Scientific untuk Siswa. Prosiding Seminar Nasional Matematika dan Pendidikan Matematika UMS 2015.

Sugiyono. (2015). Metode Penelitian Pendidikan pendekatan kuantitatif, kualitatif, dan R\&D. Bandung: Alfabeta.

Sumarmo, U. (2015). Hard-Skill Matematika: Pembelajaran dan Asesmennya. Bandung: STKIP Siliwangi.

Suryadi, D. (2013). Didactical design research (DDR) dalam Pengembangan Pembelajaran Matematika. Bandung: Universitas Pendidikan Indonesia.

Suryana, dkk. (2012). Desain Didaktis Pengenalan Konsep Pecahan Sederhana Pada Pembelajaran Matematika untuk Siswa Kelas III Sekolah Dasar. Prosiding Seminar Nasioanl Matematika dan Pendidikan matematika FMIPA UNY.

Tirtarahardja, U., \& Sulo, L.S. (2005). Pengantar Pendidikan. Jakarta: Rineka Cipta.

Uno, B.M. (2015). Teori Motivasi \& Pengukurannya. Jakarta: Bumi Aksara.

Yosmariati, dkk. (2012). Upaya Meningkatkan Kemampuan Komunikasi Matematika Siswa Melalui Pendekatan Pendidikan Matematika Realistik. Junal Pendidikan Matematika FMIPA UNP, Vol. 1, No.1. 